GLOBAL JOURNAL OF SOCIAL SCIENCES VOL 19, 2020: 13-24

COPYRIGHT@ BACHUDO SCIENCE CO. LTD PRINTED IN NIGERIA. ISSN 1596-6216 www.globaljournalseries.com; Info@globaljournalseries.com

\title{
THE INFLUENCE OF MEDIA ON POLITICAL KNOWLEDGE AMONGST UNDERGRADUATE STUDENTS IN IBADAN, NIGERIA
}

\section{OLANIRU OLUWATOSIN, OLATUNJI OLUSOJI S., AYANDELE OLUSOLA AND POPOOLA OLUGBENGA A.}

(Received 3 July 2019; Revision Accepted 17 September 2019)

\begin{abstract}
Knowledge about politics and government activities increases due to the socialization and enlightenment functions of the mass media. Youths and students are the largest bloc of voters in Nigeria but seemingly least political informed. This study examines the frequency of the forms of media accessed and level of political knowledge among Nigerian students. It also assessed the relationships between political knowledge and access to radio, television, newspaper, and social media. Moreover, it investigated the predictive influence of the frequency of media access on Nigerian students' political knowledge. The study adopted Uses and Gratification Theory (UGT) to explain how media is used to the advantage of people. Using cross-sectional survey research design, a structured questionnaire was used to collect information on students' demographic, frequency of media access and knowledge of Nigerian politics from 246 randomly selected students of the Polytechnic, Ibadan (Mean age is 25.07 years, SD $=6.23$ ). Descriptive and inferential statistics were used to analyze the data. Findings identified social media as the most frequently use media, followed by radio, television and newspaper. $31 \%$ of the respondents had very high political knowledge while $3 \%$ had no political knowledge. Access to radio is the only significant correlate $(r=0.42, p<0.05)$ and independent predictor $(\beta=0.43, t=-3.98, p<0.05)$ of political knowledge although access to radio, television, newspaper and social media are significant joint predictors of political knowledge $\left(R^{2}=.18, F(4,241)=4.32\right)$. Therefore, the study concludes that radio is the foremost source of political knowledge amongst undergraduate students in Ibadan, Nigeria. It recommends that various media institutions and political analysts should take advantage of the social media to make more audience politically knowledgeable.
\end{abstract}

KEYWORDS: Political knowledge; Mass media; Social media; Traditional media; Nigerian students.

\section{INTRODUCTION}

The mass media have always played significant roles across the globe as the general public typically relies on it to provide information regarding political issues, social issues, entertainment and news in pop culture. In advance democracies, the media is freer and more independent when it comes to journalistic content. The media are generally defined as those channels of communication which are capable of reaching heterogeneous audiences simultaneously with uniform messages (Oyesomi, Oyero, and Okorie, 2014). This diversified communication technologies are divided into traditional media and new/digital media. The three forms of traditional media are print

Olaniru Oluwatosin, Department of Public Administration, the Polytechnic, Ibadan, Nigeria.

Olatunji Olusoji S., Department of Mass Communication, the Polytechnic, Ibadan, Nigeria.

Ayandele Olusola, Department of General Studies, the Polytechnic, Ibadan, Nigeria.

Popoola Olugbenga A., Post Graduate College, American Trinity University, Porto Novo, Benin Republic

(C) 2020 Bachudo Science Co. Ltd. This work is licensed under Creative Commons Attribution 4.0 International license. 
(newspapers, books, magazines), broadcast

(television, radio), and cinema (movies, documentaries) while internet and mobile mass communication (email, social media sites, websites, and internet-based radio and television) are referred to as the new or digital media.

The notion of the media as the fourth branch of government, as watchdog, as guardian of the public interest, and as a conduit between governors and the governed is widely claimed. It is believed that an informed citizenry is beneficial to democracy. Citizens who are informed and knowledge about politics tend to make decisions that reflect their real interests. Citizens only need to watch the news, listen to the radio, read the newspaper or browse the internet or social media to receive a wide range of information (Lindstedt and Naurin 2010) which can help to promote and improve government performance and accountability (Snyder and Stromberg, 2010) as well as reduce corruption (Natamba, MuyombaTamale, Ssemakula, Nimpammya and Asiimirwe, 2010).

Citizens' participation in the political process is an important element of a democratic political culture. The participation of members of a political community is usually influenced by the political information, attitudes, feelings and skills they possessed. Cognitive orientation or political knowledge about the political system of a nation is important to the quality of citizenship and health of the collective (de Vreesea and Boomgaarden, 2006).

Political knowledge is a measure of citizen's ability to provide correct answers to a specific set of fact-based questions (Boudreau and Lupia, 2011). It depends, in part, upon access to information about governmental actions, political officeholders, and so on, and generally refers to relevant information and the level of skills and understanding of civic and political affairs surrounding regional, national and global issues (Molaei, 2017). Bathelt (2015) opined that political knowledge breed politically informed, vigilant, vocal and competent citizens who are able to evaluate their own interests and act to protect these interests in political situations. High political knowledge helps citizens to better understand the current affairs shaping their societies, contributes to more stable and consistent political attitudes. It also helps citizens to achieve their own interests and make decisions that conform to their attitudes and preferences, promotes support for democratic values, facilitates trust in the political system, and motivates political participation (Galston, 2001). While citizens that lack the minimum levels of knowledge and skills to meaningfully engage in politics can be described as political dropouts (Milner, 2010).

The media in Nigeria are sources of political information, and avenue for political participation and discussion, right from the colonial era to the present democratic dispensation. Obasanjo (1992) described it as any agency that operates for the articulation and dissemination of ideas and information, generally with the intent to influence an audience or the institution that constitutes legalized power and authority. Against this background, the contributions of media to the political knowledge of citizens over time have been a focus of social scientists and media scholars.

\section{Statement of the Problem}

The question of how those who are not very knowledgeable politically can be rendered more knowledgeable about politics by means of media exposure has been focus of research by communication experts, political scientists and other social scientists. A significant quality of political knowledge is required for citizens to be considered politically active, but most people's knowledge about politics appears insufficient to meet the standards of a "competent citizen" (DelliCarpini and Keeter, 1996; Reichert, 2016). Students, especially, have been discovered to be unwitting when it comes to national politics, news and current affairs as they mostly use the media for entertainments. Similarly, previous studies examining media access relationship with political knowledge have also produced conflicting results and explanations. The study therefore purposes to investigate if the use of media by students will have significant influence on their political knowledge. Hence, the aim of this study is to add novel findings to the small but growing empirical research on the relationship between media access and political knowledge among students of The Polytechnic Ibadan, Nigeria.

\section{Research Questions and Hypotheses}

Given the patterns of association between the media access and political knowledge, we propose to examine the possible connections between media use and political knowledge, and investigate the possible contributions of various 
media types to political knowledge by answering the following research questions:

1. What is the extent of media access among the students of The Polytechnic, Ibadan?

2. How knowledgeable are the students of The Polytechnic, Ibadan about Nigerian politics?

3. What is the influence of media access on political knowledge of Nigerian students?

In order to answer the third research question, the researchers constructed two hypotheses:

Hypothesis 1: Media access by the students will have significant relationship with their political knowledge.

Hypothesis 2: Radio, television, newspaper and social media will have significant joint and independent influence on political knowledge of Nigerian students.

\section{LITERATURE REVIEW}

\section{Uses and Gratifications Theory}

The study is based on the uses and gratifications theory (Katz, Blumler and Gurevitch, 1974) which explains the relationship between an audience and how this audience uses the media. It provides a cutting-edge theoretical approach in the initial stages of each new mass communications medium: newspapers, radio and television, and now the Internet. The theory assumes that the audience is active and its media use is goal oriented; media users are active rather than passive in seeking out media that meet their needs (Diddi and LaRose, 2006). People are rational and actively self-aware creatures that influence the effects media have on them and also unconsciously attempt to make sense of the media content in their own context. The theory also posits that users have alternate choices to satisfy their need, and their use or choice of a certain form of media (e.g. newspaper, radio, television, or internet) or a specific program (e.g. newspaper column, radio show, television channel or blog) are in order to satisfy their needs, wants, or motives (Katz et al, 1974; Peirce, 2007).

As a result, media users seek out a media source that best fulfills the needs of the users and gives them gratifications which are the expected outcomes, satisfaction or rewards of using a particular media form or program (Peirce, 2007). Similarly, Derek Lane suggests that media users play an active role in choosing and using the media. The theorist say that users take an active part in the communication process and are goal oriented in their media use. Uses and gratifications theory posits that there are five groups of human needs which are specific in nature to the individual and how the media satisfies the need is subjective (Peirce, 2007). For example, some people may watch the news to relax while others may get tensed or agitated by the same. The media is the same, but people use it for different needs. The needs are highlighted below:

1. Cognitive needs - acquiring intellectual and academic knowledge, facts, information, understanding our social environment, curiosity, exploration;

2. Affective needs - include all kinds of emotional experiences, pleasure, aesthetic, and moods of the people;

3. Personal identity - is the need for selfesteem, self-confidence, personal stability, integrity, social status, the need for self-respect and the use of media to gain credibility and have a respectable status in society;

4. Social Integrative needs - It encompasses the need to socialize with family, friends, connection with the outside world, the need for affiliation; people use social networking sites for social interaction

5. Escapism - the need to escape, tension release, shifting attention from unpleasant to pleasant. For example, people tend to relax while watching television, listening to the radio, surfing the internet, etc.

\section{Political knowledge}

Delli Carpini and Keeter (1996)defined political knowledge as the range of factual information about politics that is stored in long-term memory and listed rules of the game, substance of politics, and people and parties as the three broad areas of political knowledge. It is one's knowledge of political events, personalities, affairs, histories and institutions as measured by one's ability to provide correct answers to a specific set of fact-based questions. Low political knowledge generates a superficial understanding of public policy, intolerance of minority groups and distrust of political institutions (Hart, Atkins, Markey and Youniss, 2004). However, high political knowledge produces politically informed, vigilant, vocal and competent citizens who have needed expertise for political participation to sustain functional and stable democratic system (Bennett and Freelon, 2012).

Milner (2010) revealed that there are some politically inattentiveness citizens who lack the knowledge and skills to make sense of the political world and were unable to meaningfully 
engage in politics. In Uganda, this lack of political knowledge was identified as one of the factors that hindered the citizens from holding government officials accountable (Natamba et al, 2010). In Nigeria, students formed the largest group of voters in occupation group, accounting for $26.57 \%$ (22 million) of voters (Channels TV, 2019). Civics and Citizenship Education are taught at the various education levels to enhance students' understanding of political and social context. This knowledge can develop their confidence and motivation to participate in public life.

Furthermore, in a meta-analysis of political knowledge measurements, Delli Carpini and Keeter (1996) found that the measurements included knowledge about current national and international events, political personalities, institutions and processes. The researchers also affirmed that democratic citizens and societies need at least moderate levels of knowledge of political parties, leaders, history, economy and institutional setting to accept political norms, be politically efficacious, understand current politics and participate in politics. Citizens without a basic level of political knowledge would have difficulty in understanding political events and eventually engage in public matters (Popkin and Dimock, 1999). Therefore, higher aggregate levels of political knowledge empower societies to be more inclusive and responsive.

\section{Media and Political Knowledge}

The mass media are commonly seen as the oxygen of democratic governance and the public square for the nurturing of democratic norms and ideals (Odunlami, 2014). According to Dahlgren (2000), the free media outlets make a wide range of information accessible to the public and provide political knowledge through access to reliable and comprehensible resources such as portrayals, news, reports, discussions and so forth about social and political affairs. Likewise, Chaffee and Frank (1996) opined that textual (newspaper), auditory (radio news), and audiovisual (television) news channels should be able to provide vital information about important political and social issues. The BBC Media Action equally reported that a healthy relationship between the media and the public is needed for well-functioning democracy because informed citizenry is crucial for political accountability (Scavo and Snow, 2016).

Just like family, school, political system, religion and occupation, the media play vital roles as agents of political socialization in the society.
Access to the media has significant relationship with knowledge and attitudes (Brewer and Ley, 2010), because the general public get their news and information from mass media. According to scholars, knowledge of politics is dependent on access to and usage of news media (Möller and de Vreese, 2015; Prior, 2005). Similarly, Aalberg et al (2013) revealed a positive relationship between political news use and political knowledge. The educative roles of the traditional and new media seem to have increase political interest, discussion, and ideological sophistication in many countries (Aarts and Semetko, 2003). Therefore, the media are tools for political knowledge and democratic consolidation (Castells, 2007). The more citizens use television, radio, newspapers or internet to access the news, the higher their political knowledge which is crucial to political participation (Delli Carpini, 2000).

Widespread availability of news and political information on internet and satellite television has tendencies to improve citizens' knowledge of current events. Tewksbury, Weaver, and Maddex (2001) proved that search engine results and web portals that mixed news headlines with entertainment stories can cause accidental exposure to political information. This knowledge tends to be positively related with political knowledge. Paradoxically, Prior (2007) demonstrated that greater media choice (i.e., cable television and internet access) widens gaps in political information and electoral participation between individuals who prefer news and those who prefer entertainment.

Feldman and Kawakami (1991) in their study of 1100 Japanese undergraduates discovered that attention and exposure to newspaper is a stronger predictor of political knowledge and participation than televisions. Likewise a Canadian study noted a positive relationship between newspaper reading and political knowledge (Milner, 2005). But Aarts and Semetko (2003) found that the combined impact of television, radio, internet and social media seem to diminish the influence of newspapers and magazines on citizens' political behavior. Similarly, Prior (2007) revealed that due to satellite television there is a $20 \%$ drop in political knowledge because of viewers' preference for entertainment shows. He disclosed that the availability of multiple sources of information spread across the internet, social media, television (local and satellite), radio, newspapers and magazines is providing citizens with option 
which tend to reduce access to political information. But some scholars opined that even if news consumers care more about entertainment, sports, etc., they will nonetheless receive political information as a result of the simple act of perusing their sources of information (e.g. Tewksbury et al., 2001).

The Obama election in 2008, the Iranian postelection protests in 2009, \#Occupy wallstreet in 2011, Arab spring of 2010-2012 and \#bring back our girls in 2014 campaigns show that social media can be used effectively for political mobilization and enlightenment (Ifukor, 2010; Papic and Noonan, 2011). Just as Facebook, Twitter, Whatsapp, blogs and other social media apps were used by Nigerian youths to force down fuel price after \#Occupy Nigeria (Omojuwa, 2015) and to monitor the polls during the 2015 general elections (Mustapha, Gbonegun and Mustapha, 2016). Similarly, Bode (2016) and Molaei (2017) acknowledged that social media are rapidly emerging as important sources of news, contributing to an informed citizenry. During the 2019 general elections in Nigeria, \#Next Level\#, Atikulate and \#Takelt Back (at federal level), \#Penkelemese and \#Omituntun (in Oyo State) and \#Otoge (in Kwara state) were among the campaign hashtags and media slogans used to mobilize voters and campaign for political power.

But as media seems to increase the capacity of the voters to follow politics, the gap in the political knowledge of voters is also exacerbating (Prior, 2007) as many citizens using social media are distracted by its entertainment and communication functions (Cacciatore, Yeo, Scheufele, Xenos, Brossard and Corley, 2018; Shehata and Strömbäck, 2018). The aforementioned studies report either nonsignificant or negative main effects.

Prior (2005) acknowledged that increased access to and use of news media is related to political knowledge which according to him is influence by age, gender, or education levels. A study conducted in Sweden (Nilsson, 2005) revealed that young people nowadays browse internet and watch television while few of them read the newspaper while older people in the U.S. tend to have higher level political knowledge than young people (Wattenberg, 2003). Similarly, a study by Howe (2003) comparing responses to the political knowledge items in the 2000 Canadian Election Study to Gallop polls from 1956 concluded that the younger Canadians were less informed about politics today than people were forty-five years ago. Conclusively, the Civic and Political Health
Telephone Survey undertaken by the Center for Information and Research on Civic Learning and Engagement (CIRCLE) with a representative sample of 1,765 Americans found that about 60 percent of participants aged 15 to 25 years are potential political dropouts who know little to nothing about politics (Keeter, Zukin, Andolina, and Jenkins, 2002).

\section{METHODOLOGY}

Descriptive survey design was used as source of primary data on media access and political knowledge amongst undergraduate students, with focus on students at The Polytechnic Ibadan, Nigeria while referenced literature was the source of secondary data for the study. The survey questionnaire was administered randomly to 300consented full-time and part-time students recruited within the campuses at relaxation gardens, classrooms and departmental foyers at the Polytechnic, Ibadan between February and March 2019. The researchers were able to retrieve 290 questionnaires, 44 were excluded due to incomplete response while 246 correctly filled questionnaires ( $82 \%$ response rate) were analyzed. In addition to the demographic variables, data collected include those measuring the variables of interest in the study (media access and political knowledge).

\section{Measures}

- Demographic variables: Age was measured with an open-ended question. The male gender was assigned value " 1 " and females "2"'. Relationship Status were given value "1" for "Not dating", "2" for in "Dating" relationship and "3" for "Married".

- Media access: Brewer and Ley (2010) measured the frequency of media use, or how often one uses a particular medium to operationalize media access. The questions were presented as follows: "How frequently do you use the following media to access information?" "Radio", "Television", "Newspaper", and "Social media". Answers had a four-point response scale ranging from "almost every day" to "few times a year/never".

- $\quad$ Political knowledge: The current study measured political issue knowledge by asking respondents about five major political issues at the time of survey implementation. Assessing people's political knowledge by questioning them about history, political issues and the political system of their countries is a method frequently 
used by some scholars (Delli Carpini and Keeter, 1993; Delli Carpini and Keeter, 1996). The political knowledge is made up of variety factual questions relevant to the Nigerian context. There are two questions about political actors, two polity questions for current affairs and one for policy. A combined political knowledge index uses all 5 items as respondents received one point for each correct answer. The indices are coded as percentage of right answers from 0 to 1 . ( $\alpha=.63$, $M=3.72, S D=1.32$ ).

Table 1.1: Descriptive statistics of Respondents

\begin{tabular}{|c|c|c|c|c|c|}
\hline & Variables & Freq. & Percent & Mean & SD \\
\hline \multirow{4}{*}{$\begin{array}{l}\text { Age } \\
\text { (years) }\end{array}$} & $17-20$ & 54 & $21.95 \%$ & \multirow{4}{*}{25.07} & \multirow{4}{*}{6.23} \\
\hline & $21-25$ & 99 & $40.24 \%$ & & \\
\hline & $26-30$ & 69 & $28.05 \%$ & & \\
\hline & 31 above & 24 & $9.76 \%$ & & \\
\hline \multirow{2}{*}{ Gender } & Male & 116 & $47.15 \%$ & & \\
\hline & Female & 130 & $52.85 \%$ & & \\
\hline \multirow{3}{*}{ Marital status } & Single & 79 & $32.11 \%$ & & \\
\hline & Dating & 140 & $56.91 \%$ & & \\
\hline & Married & 27 & $10.98 \%$ & & \\
\hline
\end{tabular}

Research question 1: What is the extent of media access among the students of The Polytechnic, Ibadan? Figure 1.1 shows social media is the most frequently used medium of communication with $84.9 \%$ of respondents accessing it almost every day while $57.6 \%$, $44.7 \%$ and $28.2 \%$ accessed radio, television and newspaper respectively almost every day. $35.3 \%$ accessed television at least once weekly followed
Statistical analysis

Descriptive statistics were used for the research questions and the hypotheses were tested by Pearson's correlation analysis and multiple regression analysis using SPSS version 22 . $\mathrm{P}<0.05$ was considered statistically significant.

\section{RESULT}

A total of two hundred and forty six students, aged 17-58 years old (Mean 25.07, SD = 6.23), participated in the study. There were 130 female respondents $(52.85 \%)$ and $140(56.91 \%)$ were in dating relationship as presented in Table 1.1. by $27.1 \%$ for radio, $16.5 \%$ for newspaper and $12.9 \%$ for social media at least once weekly. $29.4 \%$ accessed newspaper at least once a month while $15.3 \%, 13 \%$ and $2.2 \%$ access television, radio and social media respectively at least once a month. Lastly, $25.9 \%, 4.7 \%$ and $2.3 \%$ accessed newspaper, television and radio respectively for few times a year/never. 
Figure 1.1: Frequency distribution for media access

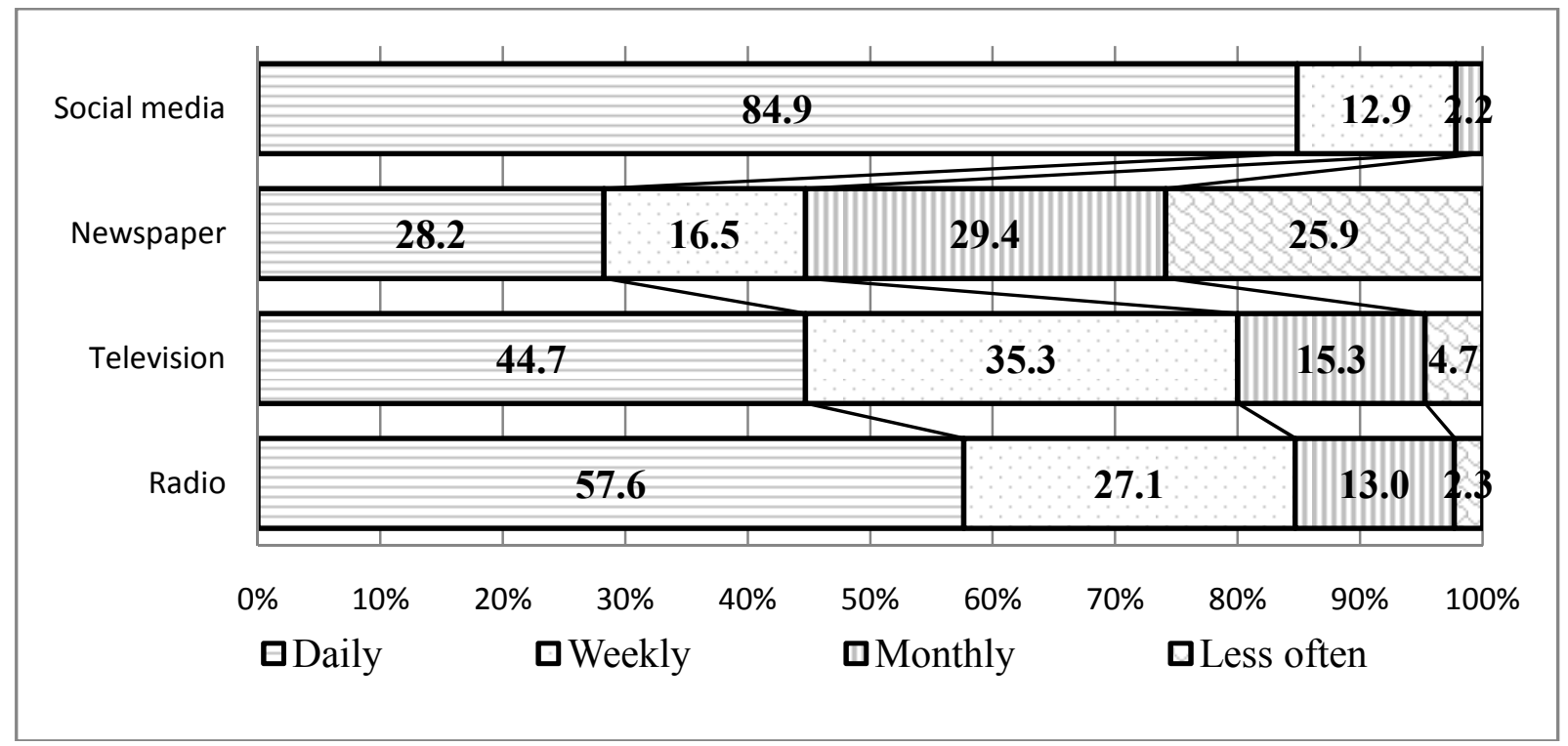

Research question 2: How knowledgeable are the students of The Polytechnic, Ibadan about Nigerian politics? Table 1.2 revealed that $89.4 \%$ of the respondents got the question on the name of the current Senate President of Nigeria correctly. $81.2 \%$ correctly gave the name of
Nigeria's Minister of Information but only $51.8 \%$ were able to guess second largest political party in Nigeria. $84.7 \%$ identified Borno as the state that suffers most from Boko Haram attacks while $65.9 \%$ knew the amount proposed an the new minimum wage in Nigeria.

Table 1.2: Questions Involving Nigerian Political Knowledge

\begin{tabular}{|l|l|l|l|}
\hline Questions & Answer & Correct & Wrong \\
\hline $\begin{array}{l}\text { 1. What is the name of the current Senate } \\
\text { President of Nigeria? }\end{array}$ & Dr Bukola Saraki & $89.4 \%$ & $10.6 \%$ \\
\hline $\begin{array}{l}\text { 2. What is the name of Nigeria's Minister of } \\
\text { Information? }\end{array}$ & Alhaji Lai Muhammed & $81.2 \%$ & $18.8 \%$ \\
\hline 3. The second largest political party in Nigeria is & $\begin{array}{l}\text { Peoples Democratic } \\
\text { Party (PDP) }\end{array}$ & $51.8 \%$ & $48.2 \%$ \\
\hline $\begin{array}{l}\text { 4. The state that suffers most from Boko Haram } \\
\text { attacks is }\end{array}$ & Borno state & $84.7 \%$ & $15.3 \%$ \\
\hline $\begin{array}{l}\text { 5. How much is the proposed new minimum wage } \\
\text { in Nigeria? }\end{array}$ & $\mathrm{N} \mathrm{30,000}$ & $65.9 \%$ & $34.1 \%$ \\
\hline
\end{tabular}

Figure 1.2 shows that $3 \%$ of the respondents missed all the political knowledge questions while $7 \%$ and $4 \%$ got just one and two questions correctly. $15 \%$ and $40 \%$ of the respondents were able to answer thee and four questions respectively but about $31 \%$ of them got all the five questions right. 
Figure 1.2: Percent of correctly answered political knowledge questions

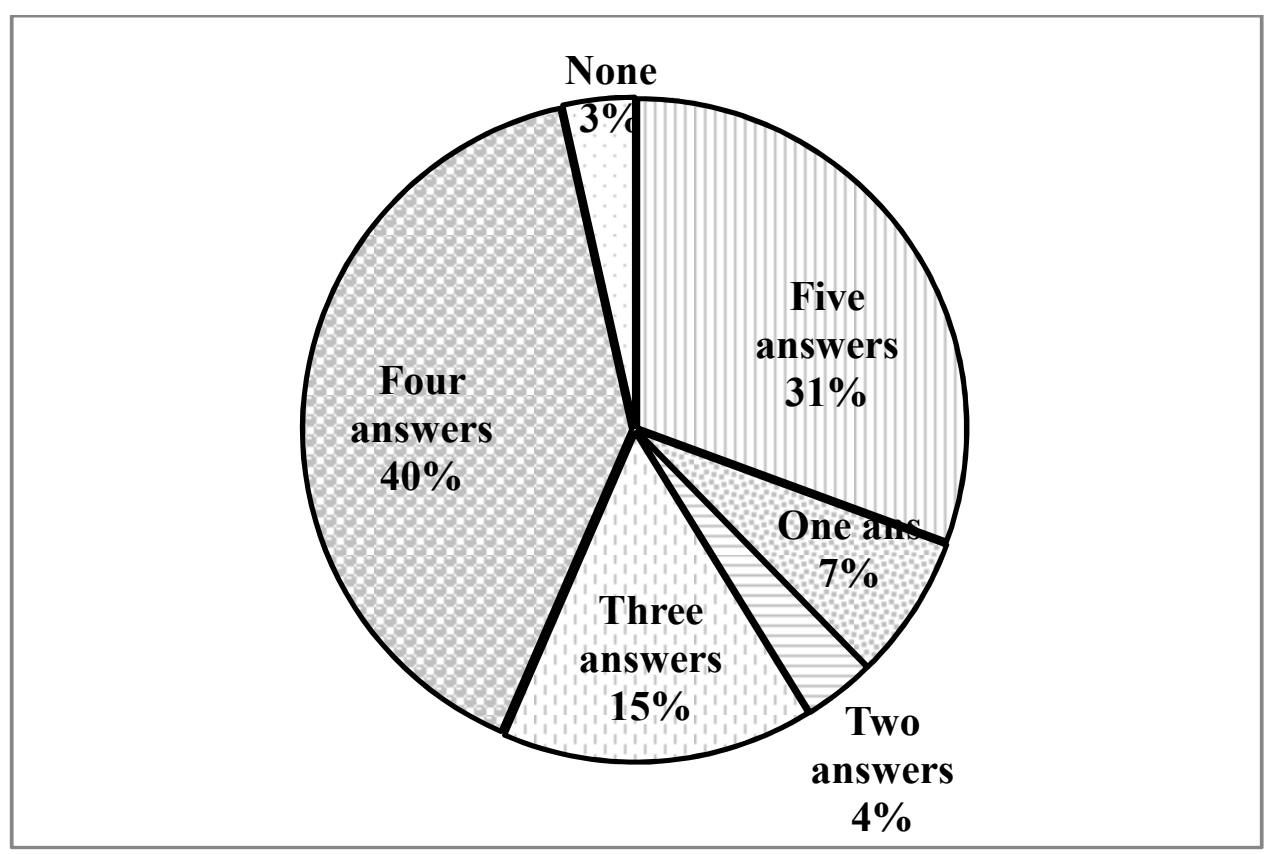

Hypothesis 1 on media access by the students will have significant relationship with their political knowledge was test and the Pearson product moment correlation coefficients in table 3 revealed a significantly positive relationship between political knowledge and radio $(r=0.42$, $p<0.00$ ) but no significant relationship with television $(r=0.04, p>0.05)$, newspaper $(r=$ $0.12, p>0.05)$ and social media $(r=-0.01$, $p>0.05$ ) (Table 1.3). This hypothesis was partially confirmed and accepted.

Table 1.3: Bivariate correlation of political knowledge with media access

\begin{tabular}{lllllll}
\hline Pearson's r correlation & 1 & 2 & 3 & 4 & Mean & S.D \\
\hline 1 Political Knowledge & - & & & & 3.73 & 1.32 \\
2 Radio & $.42^{* *}$ & - & & & 4.40 & .81 \\
3 Television & .04 & $.24^{*}$ & - & & 4.20 & .87 \\
4 Newspaper & .12 & $.32^{* *}$ & $.26^{*}$ & - & 3.41 & 1.26 \\
5 Social Media & -.01 & -.01 & $.25^{*}$ & .18 & 4.80 & .57 \\
\hline
\end{tabular}

Hypothesis 2 stated that radio, television, newspaper and social media will have significant joint and independent influence on political knowledge of Nigerian students. The hypothesis was tested using multiple regression analysis and the results presented in Table 1.4 showed that radio, television, newspaper and social media will jointly predict political knowledge of Nigerian students at $\left(\mathrm{R}^{2}=.42, \mathrm{~F}(4,242)=4.32, \mathrm{P}<.05\right)$. Similarly, political knowledge was predicted independently by radio $(\beta=0.43, t=-3.98$, $P<0.00$ ), whereas television, newspaper and social media did not independently predict political knowledge of Nigerian students. Hypothesis two is test and supported. 
Table 1.4: Summary of multiple regressions showing the independent and joint prediction of radio, television, newspaper and social media on political knowledge.

\begin{tabular}{|c|c|c|c|c|c|c|c|}
\hline Predictors & $\mathrm{R}$ & $\mathrm{R}^{2}$ & $\mathrm{~F}$ & $P$ & $\beta$ & $T$ & $p$ \\
\hline Radio & \multirow{4}{*}{.42} & \multirow{4}{*}{.18} & \multirow{4}{*}{4.32} & \multirow{4}{*}{$<.05$} & .43 & 3.98 & .00 \\
\hline Television & & & & & -.07 & -.63 & .53 \\
\hline Newspaper & & & & & -.00 & -.04 & .97 \\
\hline Social Media & & & & & .01 & .10 & .92 \\
\hline
\end{tabular}

\section{DISCUSSION OF FINDINGS}

The study examines the relationship between media access and political knowledge of Nigerian students. The findings reveal that social media is most frequently used mass media by Nigerian students followed by radio and television. This is confirmed by Odunlami (2014) and Nilsson (2005) who revealed that young people nowadays mostly browse the internet and watch television while few of them read the newspaper. The study also found that $86 \%$ of the respondents correctly answered more than 3 of the questions about political knowledge of current affairs in Nigeria. In particular, the results demonstrated that $71 \%$ of them are well-informed about political events in the country as they got more than $80 \%$ of the questions correctly, which shows high level of political knowledge. People showed a high level of knowledge regarding $\mathrm{Dr}$ Bukola Saraki, as the senate president and Borno state as the state which experienced the worst attacks of Boko haram. This result supports the assertion of Molaei (2017) that participants were well informed about the current affairs of their society. But the result contradicted Keeter et al (2002), Wattenberg (2003), Howe (2003) and Milner (2010) which concluded that many people are potential political dropouts who know little or nothing about politics.

Additionally, radio was identified as the only media that have significant relationship and predictive power on political knowledge. Most of the political news on radio in Nigeria is usually read out during "newspaper reviews" on the radio stations. Many scholars (e.g. Milner, 2005) acknowledged a positive relationship between newspaper reading and political knowledge; while they reported strong negative relationship at the aggregate level between television-watching (especially commercial television) and political knowledge. This is contrary to the assertion of Chaffee \& Frank (1996) that the impact of radio news may be less substantial on political knowledge. The lack of significant independent relationship between social media and political knowledge agreed with the findings in literature (Fraile, 2011; Livingstone \& Markham, 2008) which identified traditional news media as the most important source of political information. But this result contradicted previous findings (Kim, 2008; Wei \& Hindman, 2011) about the importance of Internet news in increasing knowledge of public affairs.

\section{CONCLUSION AND RECOMMENDATIONS}

The current study was able to clarify the effect of access to different media on political knowledge amongst undergraduate students in Ibadan, Nigeria. The study applied the uses and gratifications theory to explain the relationship between how an audience uses the media and the effect of the media usage on the audience's political knowledge. This paper revealed there is high level of political knowledge among Nigerian students and showed that listening to radio significantly influence political knowledge while social media, television and newspaper have no significant effect.

It is recommended that radio stations and other traditional media should take advantage of social media as that is where young people are active and because social media is the future of media. The cover prices of newspapers and magazines should be reduced on campuses to make the print media more accessible. Also, educational institutions should widen up the outlets through which students could have access to newspapers and magazines on a regular basis. If social media driven campaigns like \#Obama, \#Arabsprings, \#Bring Back Our Girls, \#Occupy9ja and \#Next Level could be used to enlighten and mobilize people, then it is possible to use internet and social media to boost political knowledge and participation amongst Nigerian students.

The findings furthermore raise questions for examination in future research. Future studies should further explore how media access and political knowledge influence political participation 
and voting behavior. The cross-sectional design and self-report nature of the research may lead to response biases. Generalizing the result might be limited because the study was conducted among undergraduate students.

Funding: The author has no funding to report. Competing Interests: The author has declared that no competing interests exist.

\section{REFERENCES}

Aalberg, T., Blekesaune, A., and Elvestad, E., 2013. Media choice and informed democracy: Toward increasing news consumption gaps in Europe? The International Journal of Press/Politics, 18(3):281-303.

https://doi.org/10.1177/19401612134859

$\underline{90}$.

Aarts, K. and Semetko, H. A., 2003. The Divided Electorate: Media Use and Political Involvement. The Journal of Politics.65(3): $\quad$ 759-784. http://www.jstor.org/stable/3449494.

Bathelt, S., 2015. Political Knowledge - Mediator of Political Participation? Paper presented at the General Conference of the European Consortium for Political Research (ECPR) 26 - 29 August 2015. Montréal, Canada.

Bennet, W. L., 2012. The Personalization of Politics: Political Identity, Social Media, and Changing Patterns of Participation. The ANNALS of the American Academy of Political and Social Science, 644:2039.

Bennett, W. L. and Freelon, D., 2011. Communicating Civic Engagement: Contrasting Models of Citizenship in Youth Web Sphere. Journal of Communication, 61 (5): 835-856.

Bode, L., 2016. Political news in the news feed: Learning politics from social media. Mass Communication and Society, 19, 24-48. doi:10.1080/15205436.2015.1045149.

Boudreau, C. and Lupia, A., 2011. Political knowledge. In J. Druckman, D. Green, J. Kuklinski and A. Lupia (Eds.), Cambridge
Handbook of Experimental Political Science pp

171-186. Cambridge, England: Cambridge University Press.

Brewer, P. R., and Ley, B. L., 2010. Media use and public perceptions of DNA evidence. Science Communication 32(1), 93-117.

Cacciatore, M. A., Yeo, S. K., Scheufele, D. A., Xenos, M. A., Brossard, D., and Corley, E. A., 2018. Is Facebook Making Us Dumber? Exploring Social Media Use as a Predictor of Political Knowledge. Journalism and Mass Communication Quarterly, 95:404-424. doi:10.1177/1077699018770447.

Castells, M., 2007. Communication, power and counter-power in the network society. International Journal of Communication, 1(1), 238-266.

Chaffee, S. and Frank, S., 1996. How Americans get Political Information: Print versus Broadcast News. The Annals of the American Academy of Political and Social Science, 546:48-58.

Channels TV February 7, 201984 millions Nigerians registered to vote; Kano top list. Available at www.channelstv.com/2019/02/07 84million-Nigerians-Registered-to-voteLagos-Kano-top-list. Accessed on May 3, 2019.

Dahlgren, P., 2000. The Internet and the democratization of civic culture. Political Communication, 17,335-340.

deVreesea, C. H. and Boomgaarden, H., 2006. News, Political Knowledge and Participation: The Differential Effects of News Media Exposure on Political Knowledge and Participation. Acta Politica, 41, 317-341.

Delli Carpini, M. X., 2000. Gen.com: Youth, civic engagement, and the new information environment. Political Communication 17:341-49.

Delli Carpini, M. X. and Keeter, S., 1993. Measuring Political Knowledge: Putting 
First Things First. American Journal of Political Science 37(4): 1179-206.

Delli Carpini, M. X. and Keeter, S., 1996. What Americans Know about Politics and Why It Matters. Yale University Press.

Diddi, A. and La Rose, R., 2006. Getting Hooked on News: Uses and Gratifications and the Formation of News Habits Among College Students in an Internet Environment. Journal of Broadcasting and Electronic Media 50 (2):193-210.

Feldman, O. and Kawakami, K., 1991. Media use as predictors of political behavior: The case of Japan. Political Psychology, 12(1):65-80. Doi:10.2307/3791346.

Fraile, M., 2011. Widening or reducing the knowledge gap? Testing the media effects on political knowledge in Spain 2004-2006. Harvard International Journal of Press/Politics, 16(2), 163-184.

Galston, W. A., 2001. Political knowledge, political engagement, and civic education. Annual Review of Political Science, $\quad 4, \quad 217-234$. doi:10.1146/annurev.polisci.4.1.217.

Hart, D., Atkins, R., Markey, P., and Youniss, J., 2004. Youth bulges in communities: The effects of age structure on adolescent civic knowledge and civic participation. Psychological Science 15 (9): 591-597.

Howe, P., 2003. Where Have All the Voters Gone. Inroads 12:75-82.

Ifukor, P., 2010. 'Elections' or 'Selections'? Blogging and Twittering the Nigerian 2007 General Elections.' Bulletin of Science, Technology and Society.

Katz, E., Blumler, J. G., and Gurevitch, M., 1974 Uses and gratifications research. Public Opinion Quarterly 37(4): 509-523.

Keeter, S., Zukin, C., Andolina, M. and Jenkins, K., 2002. The Civic and Political Health of the Nation: A Generational Portrait. College Park, MD: Center for Information and Research on Civic Learning and
Engagement (CIRCLE); Pew Charitable Trusts.

Kim, S-H., 2008. Testing the knowledge gap hypothesis in South Korea: Traditional news media, the Internet, and political learning. International Journal of Public Opinion Research, 20(2), 193-210.

Lindstedt, C. and Naurin, D., 2010. Transparency is not Enough: Making Transparency Effective in Reducing Corruption. International Political Science Review 31(3):301-322.

Livingstone, S., and Markham, T., 2008. The contribution of media consumption to civic participation. British Journal of Sociology, 59(2), 351-371.

Milner, H., 2005. Are Young Canadians Becoming Political Dropouts? A Comparative Perspective. IRPP Policy Matters 11, no. 3, June 2005.

Milner, H., 2010. Political Attentiveness, Nonmaterial Redistribution, and the Problem of Political Dropouts. Paper presented at joint sessions the European Consortium for Political Research (ECPR), March 2227, 2010. Muenster Germany,

Molaei, H., 2017. Social Media and Politics: Examining Indonesians' Political Knowledge on Facebook. Journal of Cyberspace Policy Studies, 1(1):119139. DOI: 10.22059/jcpolicy.2017.59873.

Möller, J., and de Vreese, C. H., 2015. Spiral of political learning: The reciprocal relationship of news media use and political knowledge among adolescents. Communication Research, advance online access. https://doi.org/10.1177/00936502156051 48.

Mustapha, L. K., Gbonegun, V. O., and Mustapha, M. L., 2016. Social Media Use, Social Capital, and Political Participation among Nigerian University Students. Trípodos, número 39: 127-143.

Natamba, E. F., Muyomba-Tamale, L., Ssemakula, E., Nimpammya, E., and Asiimirwe, I., 2010. Local government councils 
performance and the quality of service delivery in Uganda: Ntungamo District Council Score-card 2008/9, No. 39 (Advocates Coalition for Development and Environment, Kampala, Uganda). Available www.acodeu.org/Files/Publications/PRS 39.pdf.Accessed May 19, 2018.

Nilsson,

A., 2005.

Tidningsläsandetsåldrarochgenerationer. In Nypressat. Ettkvartssekel med svenskadagstidningsläs are, edited by $\mathrm{L}$. Weibull, I. Wadbring and A. Bergström. Göteborg: Göteborgs universitet

Obasanjo, O., 1992. Elements of democracy. Abeokuta, Nigeria: ALF Publication.

Odunlami, D., 2014. Media Access and Exposure as Determinants of the Political Knowledge of Nigerian Undergraduates. New Media and Mass Communication, 28:5-15

Omojuwa, J., 2015. Social Media and 2015 Election: Beyond APC vs PDP http://www.naij.com/38815-social -media 2015 elections for naijacom.html. Assessed on December 15, 2018.

Oyesomi, K., Oyero, O., and Okorie, N., 2014. Media advocacy, development journalism and Child rights issues in Nigeria. Scholar Journal of Arts, Humanities and Social Sciences. 2(2B): 261-265. Available

at

http://saspjournals.com/wpcontent/uploa ds/2014/03/SJAHSS-22B261-265.pdf. Accessed December 24, 2018.

Papic, M., and Noonan, S., 2011. Social Media as a tool for protest. Available at http://www.stratfor.com/weekly.Accessed on December 20, 2018.

Peirce, K., 2007. Uses and Gratifications Theory. In Encyclopedia of Children, Adolescents, and the Media Vol. 2, pp. 841-843. Thousand Oaks, CA: SAGE Reference.

Popkin, S. L., and Dimock, M. A., 1999. Political knowledge and citizen competence. In S. L. Elkin and K. E. Soltan (Eds.), Citizen Competence and Democratic Institutions (pp. 117-146). University Park, PA: Pennsylvania State University Press.
Prior, M., 2005. News versus Entertainment: How Increasing Media Choice Widens Gaps in Political Knowledge and Turnout. American Journal of Political Science 49(3): 577-92.

Prior, M., 2007. Post-broadcast Democracy: How Media Choice Increases Inequality in Political Involvement and Polarizes Elections. Cambridge: Cambridge University Press.

Reichert, F., 2016. How Internal Political Efficacy Translates Political Knowledge Into Political Participation: Evidence From Germany. Europe's Journal of Psychology, 12(2): 221-241, doi:10.5964/ejop.v12i2.1095.

Scavo, A., and Snow, C., 2016. Media and Political Participation: fostering inclusive governance. BBC Media Action's Research Report, issue no. 10. October 2016.

Shehata, A., and Strömbäck, J., 2018. Learning Political News From Social Media: Network Media Logic and Current Affairs News Learning in a High-Choice Media Environment. Communication Research, 0093650217749354.

Snyder, J. M. Jr., and Stromberg, D., 2010. Press Coverage and Political Accountability. Journal of Political Economy 118 (2): 355-408.

Tewksbury, D., Weaver, A. J., and Maddex, B. D., 2001. Accidentally informed: Incidental news exposure on the World Wide Web. Journalism and Mass Communication Quarterly 78(3): 533554.

Wattenberg, M., 2003. Electoral Turnout: The New Generation Gap. Journal of Elections, Public Opinion and Parties.13(1): 159-73.

Wei, L., and Hindman, D. B., 2011. Does the digital divide matter more? Comparing the effects of new media and old media use on the education-based knowledge gap. Mass Communication and Society, 14(2), 216235 